\title{
Original Paper / Artigo Original In vitro culture and acclimatization of Cattleya xanthina (Orchidaceae), an endangered orchid of the Brazilian Atlantic Rainforest
}

\author{
Monique Cristine R. Juras ${ }^{1,5}$, Jackeline Jorge ${ }^{1}$, Rosete Pescador ${ }^{2}$, Wagner de Melo Ferreira ${ }^{3}$, VivianTamaki ${ }^{4}$ \\ \& Rogério M. Suzuki ${ }^{1}$
}

\begin{abstract}
Cattleya xanthina is a Neotropical orchid endemic to the Brazilian Atlantic Rainforest, at high risk of extinction. In this paper, we investigated the effects of different culture media on C. xanthina as well as on their endogenous nitrogen status. Culture media studied: Knudson C (KC), Vacin and Went (VW), and Murashige and Skoog (MS), the latter used at two different concentration (full and half-strength; MS/2). After 180 days, plants were transferred to MS medium with different NAA and BA concentrations. In each treatment, biometric parameters were measured and the endogenous levels of photosynthetic pigments, total protein, nitrate and ammonium ions were quantified. Plants grown on $\mathrm{KC}$ medium had the lowest concentration of nitrogen but exhibited the greatest shoot development, production of photosynthetic pigments and total protein. Results of growth regulators showed that the highest concentration of auxin stimulated root development and the production of photosynthetic pigments, and that a higher concentration of cytokinin promoted protein synthesis and the development of shoots. Most successful acclimatization was obtained when a mixture of Sphagnum and Pinus bark was used as the substrate.
\end{abstract}

Key words: Auxin, conservation, cytokinin, ex vitro, nitrogen.

\section{Resumo}

Cattleya xanthina é uma orquídea neotropical endêmica da Mata Atlântica brasileira, com alto risco de extinção. Neste trabalho analisamos diferentes meios de cultura sobre o desenvolvimento de $C$. xanthina, e seu status de nitrogênio endógeno. Meios de cultura estudados: Knudson C (KC), Vacin \& Went (VW) e Murashige \& Skoog (MS), e o meio MS com metade da concentração de nutrientes (MS/2). Após 180 dias, as plantas foram transferidas para o meio MS com diferentes concentrações de NAA e BA. Em cada tratamento, foram analisados parâmetros biométricos e níveis endógenos de pigmentos fotossintéticos, proteína total, nitrato e íons de amônio. As plantas cultivadas em meio $\mathrm{KC}$ apresentaram menor concentração de nitrogênio, mas exibiram o maior desenvolvimento, produção de pigmentos fotossintéticos e proteína total. Os resultados dos reguladores de crescimento mostraram que a maior concentração de auxina estimulou o desenvolvimento radicular e a produção de pigmentos, e a maior concentração de citocinina promoveu síntese proteica e o desenvolvimento caulinar. A aclimatização mais bem sucedida foi obtida quando uma mistura de Sphagnum e casca de Pinus foi usada como substrato.

Palavras-chave: Auxina, conservação, citocinina, ex-vitro, nitrogênio.

\footnotetext{
${ }^{1}$ Instituto de Botânica, Núcleo de Pesquisa - Orquidário do Estado, 04301-012, São Paulo, SP, Brazil.

${ }^{2}$ Universidade Federal de Santa Catarina, Pós-graduação em Recursos Genéticos Vegetais, Rod. Admar Gonzaga, km 3, Itacorubi, 88034-001, Florianópolis, SC, Brazil.

${ }^{3}$ Universidade Federal de Tocantins, Núcleo de Estudos Ambientais (NEAMB), C.P. 111, 77500-000, Porto Nacional, TO, Brazil.

${ }^{4}$ Instituto de Botânica, Núcleo de Pesquisa em Plantas Ornamentais, 04301-902, São Paulo, SP, Brazil.

${ }^{5}$ Author for correspondence: monique_cristine13@yahoo.com.br
} 


\section{Introduction}

Cattleya xanthina (Lindl.) Van den Berg is an endangered, epiphytic species that has been categorized as "under threat" by the Brazilian Ministry of the Environment (MMA 2014). According to Hoehne (1953), this species is endemic to the Atlantic Rainforest, occurring from southern Bahia to the Rio de Janeiro states. Human action is causing habitat destruction and subsequent population decline of orchid species. Furthermore, the fact that orchids go through a long vegetative period before reaching reproductive phase as well as their complex life-cycle increase the risk of extinction (Ferreira \& Suzuki 2008). Thus, in vitro culture is an effective alternative to avoid orchid extinction, since it promotes increased germination rates and enables seedling production in short periods, which contributes to species conservation.

Previous studies related to other endangered orchids have demonstrated that the development of seedlings varies among species and is dependent, among other factors, on the culture medium (Dutra et al. 2008; Suzuki et al. 2009, 2010). Therefore, studies that investigate the importance of different nutrients, especially nitrogen, are very relevant to understanding the efficacy of the culture medium. Nitrogen can be assimilated by plants in the form of nitrate $\left(\mathrm{NO}_{3}^{-}\right)$or ammonium $\left(\mathrm{NH}_{4}^{+}\right)$ions. Generally, nitrate is the form of nitrogen most readily taken up by plants, although this may vary among species and may be influenced by environmental factors (Mengel \& Kirkby 1978). According to Malavolta et al. (1997), the chlorophyll content present in plant tissues indicates the level of nitrogen absorbed. As it makes part of the chlorophyll molecule, nitrogen is critical to plant growth and any deficiency affects light absorption during photosynthesis, negatively influencing plant development (Cheng 2003).

Growth regulators have also been broadly used for the in vitro culture of orchids since they promote germination and development. Kuiper et al. (1988) affirm that nutrient availability can influence the synthesis and action of endogenous phytohormones, and nitrogen, in particular, can affect plant levels of auxin and cytokinin.

Population decline and the consequent threat to Cattleya xanthina in Brazil, besides the absence of studies concerning its propagation, confirm the importance of optimizing in vitro protocols for its germination and optimal development, allowing its conservation and reintroduction into natural environments.
Taking the above into consideration, this study aimed to analyze the influence of different culture media and growth regulators on the development of plants of $C$. xanthina as well as on their endogenous nitrogen status. Plant acclimatization was also performed.

\section{Material and Methods}

Plants and culture medium

Seedlings of Cattleya xanthina were produced in vitro by using seeds collected from eight fruits of plants belonging to the Orchid Collection of the Institute of Botany Research Center - Orchidarium of São Paulo state, Brazil. These seeds were grown in Murashige \& Skoog medium and maintained under the same growing conditions of this paper.

The following culture media were used in the experiments: Knudson $\mathrm{C}$ ( $\mathrm{KC}$; Knudson 1946), Vacin \& Went (VW; Vacin \& Went 1949) and Murashige \& Skoog (MS; Murashige \& Skoog 1962); the latter was used at two different macro- and micronutrient concentrations (full and half-strength, MS and MS/2). All media were supplemented with 20 g.L L $^{-1}$ sucrose (Vetec Quimica, Sigma-Aldrich, Rio de Janeiro, Brazil) and $0.4 \%$ bacteriological agar (Vetec Quimica, Sigma-Aldrich, Rio de Janeiro, Brazil), and the $\mathrm{pH}$ was adjusted to 5.8 (PA200, Marconi, Piracicaba, SP, Brazil). The media were autoclaved at 117.7 $\mathrm{kPa}$ and $121^{\circ} \mathrm{C}$ for $15 \mathrm{~min}$ (Ibacli S.A., São Paulo, Brazil). Cultures were maintained in a growth room at $25 \pm 2{ }^{\circ} \mathrm{C}$ and a photoperiod of $12 \mathrm{~h}$ at $30 \mu \mathrm{Mm}^{-2}$ $\mathrm{s}^{-1}$ PAR (GE Lighting, São Paulo, Brazil).

Experiment I (Influence

of culture media)

In this experiment, 15 six-month-old seedlings $(0.6 \pm 0.1 \mathrm{~cm}$ in length) originating from in vitro culture, had all roots removed and were placed in flasks containing $\mathrm{KC}, \mathrm{VW}, \mathrm{MS}$ and $\mathrm{MS} / 2$ media. Seven flasks per culture medium were used $(\mathrm{n}=$ 105). Data was collected after 180 days of culture.

Experiment II (Influence of naphthaleneacetic acid and benzyladenine)

In this experiment 15 plants $(0.8 \pm 0.1 \mathrm{~cm}$ in length), originating from the MS medium of experiment $\mathrm{I}$, had all roots removed and were transferred to flasks containing fresh MS medium supplemented with auxin $(\alpha$-naphthaleneacetic acid - NAA) and cytokinin (6-benzyladenine - BA) used 
in combinations of $0,0.57$ and $2.28 \mu \mathrm{M}$. There was a total of nine treatments and seven flasks were used per treatment $(n=105)$. Data were collected after 180 days of culture.

\section{Biometric parameters}

For both experiments described above, eight plants from each treatment were randomly selected and evaluated in terms of shoot and root (longest) lengths, number of leaves and roots, and fresh and dry mass of shoots and roots. The dry mass was determined after drying the plants at $60{ }^{\circ} \mathrm{C}$ to constant weight (Approximately one week).

Quantification of $\mathrm{NH}_{4}{ }^{+}$and $\mathrm{NO}_{3}{ }^{-}$

Analysis of ammonium $\left(\mathrm{NH}_{4}^{+}\right)$and nitrate $\left(\mathrm{NO}_{3}{ }^{-}\right)$was performed in plant material originated from Experiment I. Three $500 \mathrm{mg}$ samples of fresh material (including shoots and roots, approximately 10 plants) were used for quantification and each sample was analyzed three times $(n=9)$. The fresh material was previously macerated in ultrapurified water, centrifuged at 12,000 rpm for $30 \mathrm{~min}$ and the supernatant was used for determination of $\mathrm{NH}_{4}^{+}$ and of $\mathrm{NO}_{3}{ }^{-}$. Quantification of $\mathrm{NH}_{4}{ }^{+}$was performed according to Weatherburn (1967) and as modified by Magalhães et al. (1992). Samples were analyzed in a spectrophotometer (U2M, Quimis, São Paulo, Brazil) at $625 \mathrm{~nm}$. $\mathrm{NH}_{4} \mathrm{Cl}$ was used to establish the standard curve. The method proposed by Cataldo et al. (1975), was used for $\mathrm{NO}_{3}^{-}$determination. Absorbance was read at $410 \mathrm{~nm}$. $\mathrm{KNO}_{3}{ }^{-}$was used as the standard.

\section{Quantification of photosynthetic} pigments

Quantification of chlorophyll and carotenoids was carried out according to Lichtenthaler (1987) in plant material originated from both experiments. Three $300 \mathrm{mg}$ samples of fresh material (including shoots and roots, approximately six plants) were used for quantification and each sample was analyzed three times $(\mathrm{n}=9)$. The fresh material was previously macerated in $80 \%$ cold acetone and filtrate, under low- light conditions. After filtration, the absorbance was read at $662 \mathrm{~nm}, 645 \mathrm{~nm}$ and $470 \mathrm{~nm}$ in a spectrophotometer.

\section{Total protein quantification}

Quantification of total protein was carried out according to Bradford (1976) in plant material originating from both experiments. Three $350 \mathrm{mg}$ samples of fresh material (including shoots and roots, approximately seven plants) were used for quantification and each sample was analyzed three times $(n=9)$. The fresh material was previously macerated in phosphate buffer, centrifuged at $12,000 \mathrm{rpm}$ for $30 \mathrm{~min}$. The supernatant were collected and combined with Comassie Brilliant Blue G-250. The protein standard curve was obtained with Coomassie Brilliant Blue G-250 and bovine serum albumin. The absorbance was read at $595 \mathrm{~nm}$ in a spectrophotometer.

\section{Acclimatization}

Plants obtained from the original in vitro culture, 540 days of cultivation, with shoot length of about $2 \mathrm{~cm}$ and roots presence, were transferred to pots containing two different substrates: Sphagnum and a mixture of Sphagnum and Pinus bark (50:50 v/v). Five pots containing five plants were used for each substrate, the pots were maintained in greenhouse (combination of masonry and glass), with $80 \%$ of shading and a nebulization irrigation system one times per day. The plants received bi-weekly applications of the NPK fertilizer (Peters 20:20:20). Biometric data (number of leaves and shoot length) were collected after 180 days of cultivation. Root length and fresh and dry mass of shoots and roots were not collected as plants were subsequently used in a reintroduction program.

\section{Statistical analysis}

The results from the in vitro experiments were submitted to an analysis of variance (ANOVA) and the means were compared by the Tukey test at a $5 \%$ probability level. Ex vitro cultivation data were submitted to Fisher's analysis of variance by using the SPSS 20 software.

\section{Results}

\section{Experiment I}

After 180 days of culture (Fig. 1), the biometric parameters of Cattleya xanthina plants revealed that the greatest shoot length was obtained on $\mathrm{KC}$ medium $(1.4 \mathrm{~cm})$. However, there was no significant difference among the culture media assessed (Fig. 2a). Regarding average root length (Fig. 2a), plants grown on MS/2 and VW media showed the best results $(1.9$ and $1.8 \mathrm{~cm}$, respectively). Leaf number was not influenced by culture medium (Fig. 2b), but MS inhibited root production. 
There was no significant difference among the culture media in terms of shoot fresh mass (Fig. 2c), although the best result was obtained on $\mathrm{KC}$ medium. Root fresh mass was greater on VW medium (40.9 mg), followed by the MS/2 and $\mathrm{KC}$ media (26.7 and $25.3 \mathrm{mg}$, respectively) (Fig. 2c). KC medium showed higher shoot dry mass accumulation $(4.3 \mathrm{mg})$ compared to MS, $\mathrm{MS} / 2$, and VW (2.6, 2.5, $2.2 \mathrm{mg}$, respectively)
(Fig. 2d). Root dry mass was greater on MS/2 medium $(7.2 \mathrm{mg})$ in comparison with $\mathrm{VW}, \mathrm{KC}$ and MS media (2.7, 2.6 and $0.8 \mathrm{mg}$, respectively) (Fig. 2d). Although MS exhibited the worst performance in terms of biometric parameters, plant survival was highest on this medium (data not shown).

The endogenous level of ammonium was highest in plants grown on $\mathrm{KC}$ medium (60.6

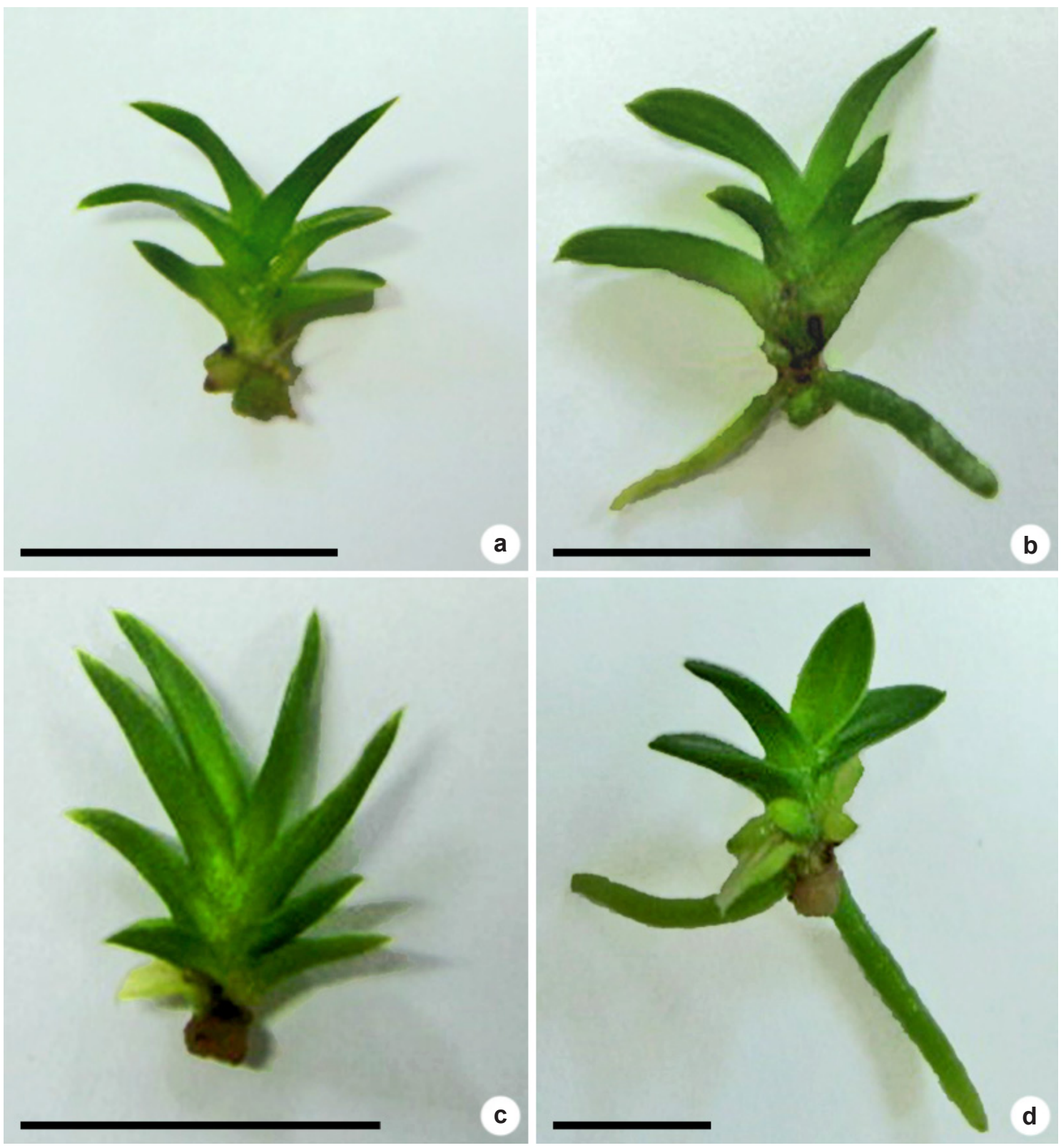

Figure 1 - a-d. Plants of Cattleya xanthina grown in vitro for 360 days in different culture media - a. KC medium; b. VW medium; c. MS medium; d. MS $/ 2$ medium. Scale bar $=1 \mathrm{~cm}$. 

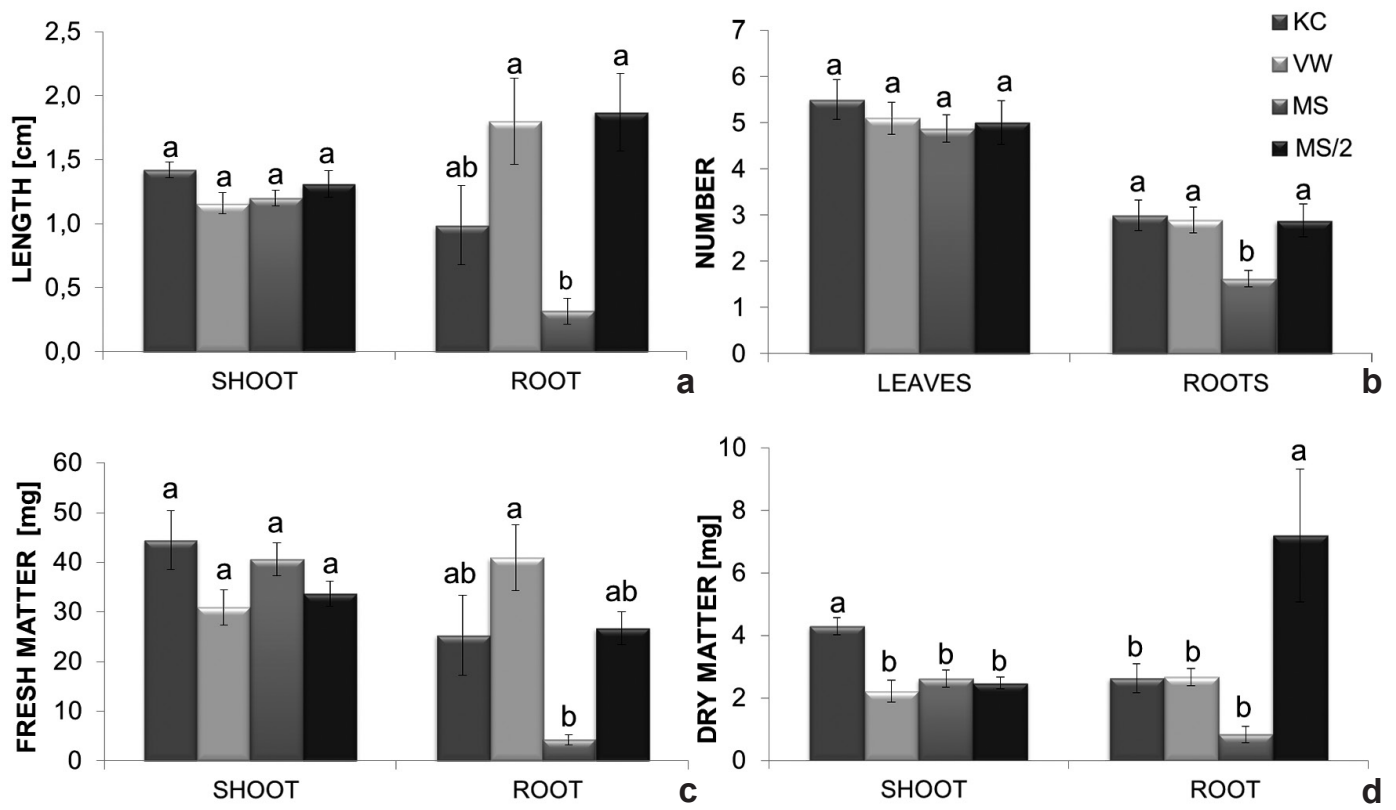

Figure 2 - a. Effects of different culture media on Cattleya xanthina shoot and longest root length. b. Number of leaves and roots. c. Fresh mass. d. Dry mass. Bars represent the standard error of the mean. Histobars with the same letters are not significantly different according to the Tukey's test at a $5 \%$ probability level $(\mathrm{n}=8)$.

$\left.\mu \mathrm{g} . \mathrm{g}^{-1} \mathrm{FM}\right)$. Contrarily, on MS/2 medium plants exhibited the lowest level (15.1 $\mu \mathrm{g} \mathrm{NH}{ }_{4}^{+} \cdot \mathrm{g}^{-1}$ FM) (Fig. 3b). Plants grown on MS medium had higher nitrate levels in comparison with the other culture media (Fig. 3a), reaching 683.7 $\mu \mathrm{g}$ nitrate $\mathrm{g}^{-1} \mathrm{FM}$, while plants grown on $\mathrm{VW}, \mathrm{MS} / 2$ and $\mathrm{KC}$ media had 221.8, 171.8 and $40.6 \mu \mathrm{g}$ of nitrate. $\mathrm{g}^{-1} \mathrm{FM}$, respectively.

In general, the synthesis of photosynthetic pigments was stimulated by KC medium (227.1
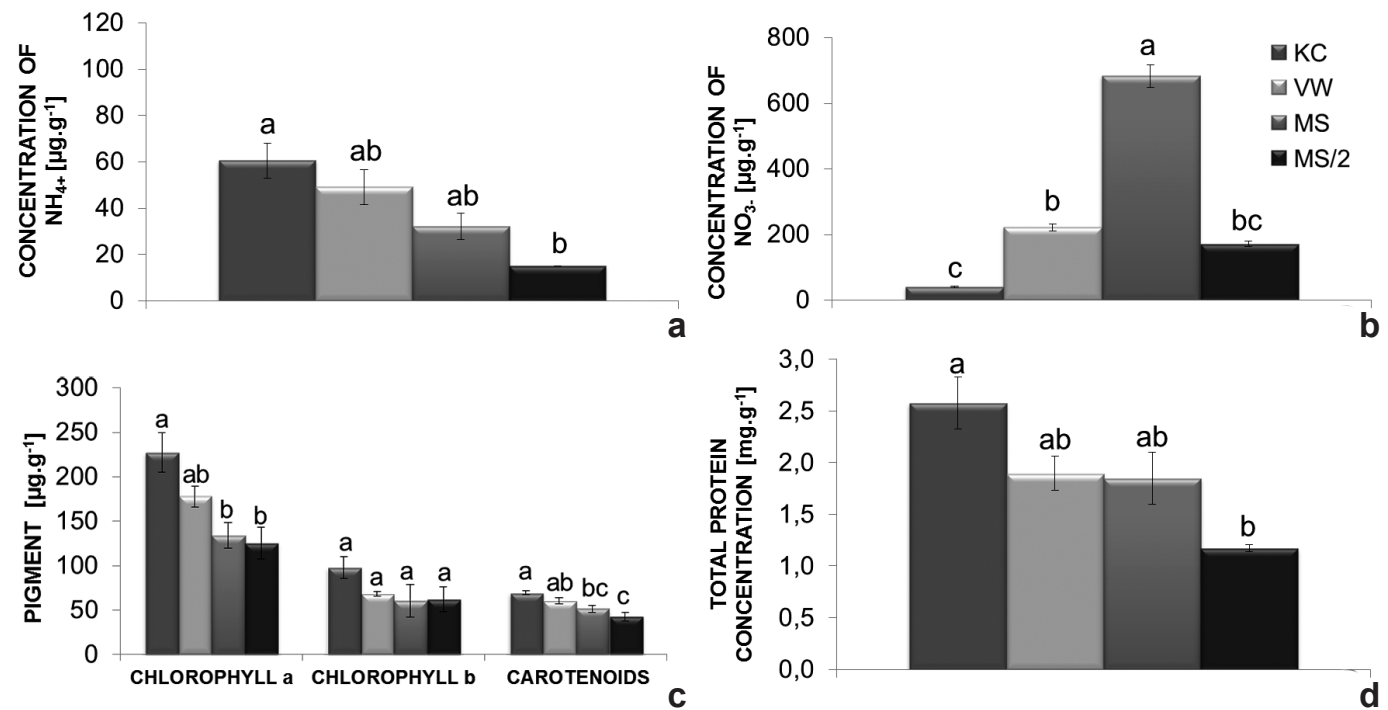

Figure 3 - a-d. Endogenous nitrogen levels of Cattleya xanthina plants grown on different culture media - a. nitrate; b. ammonium; c. photosynthetic pigments; d. total protein. Bars represent the standard error of the mean. Histobars with the same letters are not significantly different according to the Tukey's test at a 5\% probability level $(n=9)$. 
$\mu \mathrm{g}$ of chlorophyll $a . \mathrm{g}^{-1} \mathrm{FM}, 98.1 \mu \mathrm{g}$ of chlorophyll $b . \mathrm{g}^{-1} \mathrm{FM}$ and $69.5 \mu \mathrm{g}$ of carotenoids. $\mathrm{g}^{-1} \mathrm{FM}$ ). Nevertheless, the amounts of chlorophyll $b$ did not significantly differ among the culture media investigated (Fig. 3c).

The highest amount of total protein was found in plants grown on $\mathrm{KC}$ medium ( $\left.2.5 \mathrm{mg} \mathrm{g}^{-1}\right)$, while plants on MS/2 medium had the lowest levels of total protein $\left(1.2 \mathrm{mg} . \mathrm{g}^{-1}\right)$ (Fig. 3d).
Experiment II

The different combinations of benzyladenine and naphthaleneacetic acid promoted different root- and shoot-development responses. In the control treatment (hormone-free MS medium) plants exhibited shorter shoots and fewer leaves. Some treatments inhibited root formation (Fig. 4).

The shortest shoots $(0.9 \mathrm{~cm})$ were observed in the control treatment whereas the longest ones were

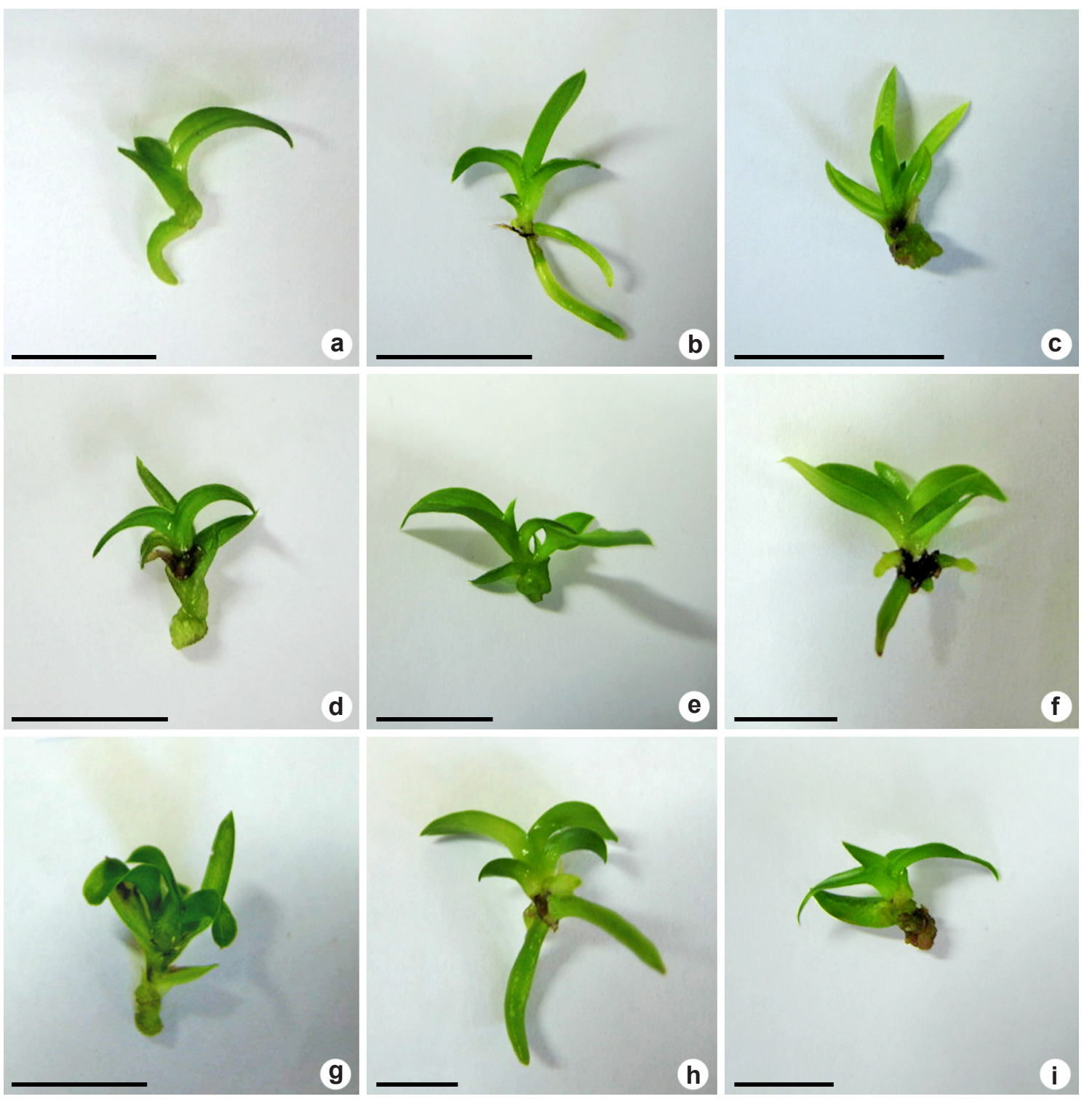

Figure 4 - a-i. Plants of Cattleya xanthina grown in vitro for 540 days on MS medium containing NAA and BA - a. MS; b. MS + 0.57 uM NAA; c. MS + 2.28 uM NAA; d. MS + 0.57 uM BA; e. MS+ 2.28 uM BA; f. MS + 0.57 uM $\mathrm{NAA}+0.57 \mathrm{uM} \mathrm{BA}$; g. MS + $0.57 \mathrm{uM} \mathrm{NAA}+2.28 \mathrm{uM} \mathrm{BA} ;$ h. MS+ $2.28 \mathrm{uM} \mathrm{NAA}+0.57 \mathrm{uM} \mathrm{BA} ;$ i. $\mathrm{MS}+2.28 \mathrm{uM}$ $\mathrm{NAA}+2.28 \mathrm{uM}$ BA. Scale bar $=1 \mathrm{~cm}$. 
obtained on MS medium supplemented with 0.57 $\mu \mathrm{MNAA}+2.28 \mu \mathrm{M}$ BA $(1.6 \mathrm{~cm})$. Regarding root development, none of the treatments significantly differed from the control, although they varied between 0.2 and $0.6 \mathrm{~cm}$ in terms of length (Fig. 5a).

Leaf number was significantly influenced by naphthaleneacetic acid and benzyladenine. Plants grown on MS enriched with $0.57 \mu \mathrm{MNAA}+2.28$ $\mu \mathrm{M}$ BA showed a greater number of leaves $(9$ leaves) when compared to the control treatment (5 leaves) (Fig. 5b). The greatest root production was obtained on MS supplemented with $0.57 \mu \mathrm{M}$ NAA (approximately 3 roots per plant). Plants grown on MS enriched with 0.57 or $2.28 \mu \mathrm{M}$ BA exhibited the smallest number of roots $( \pm 0.8$ root per plant) (Fig. 5b).

Shoot fresh mass was significantly affected by the action of plant hormones. MS medium enriched with $2.28 \mu \mathrm{M} N A A+0.57 \mu \mathrm{M}$ BA provided the greatest fresh mass production $(70.5$ $\mathrm{mg}$ ) followed by that supplemented with $0.57 \mu \mathrm{M}$ $\mathrm{NAA}+2.28 \mu \mathrm{M}$ BA $(61.4 \mathrm{mg})$ (Fig. 5c). The additions of $0.57 \mu \mathrm{M}$ BA, $2.28 \mu \mathrm{M}$ BA, $2.28 \mu \mathrm{M}$ $\mathrm{NAA}$ and $2.28 \mu \mathrm{M} \mathrm{NAA}+2.28 \mu \mathrm{M} \mathrm{BA}$ to the MS medium were inhibitory (respectively $0.6,1.2,1.4$ and $2.2 \mathrm{mg}$ ) to root fresh mass accumulation when compared to the control treatment $(4.4 \mathrm{mg}$ ) (Fig. $5 \mathrm{c})$. NAA at $0.57 \mu \mathrm{M}$ NAA $(12.4 \mathrm{mg})$ was the only treatment that surpassed the control.

MS supplemented with $2.28 \mu \mathrm{M}$ NAA + $0.57 \mu \mathrm{M}$ BA $(6.2 \mathrm{mg})$ and $0.57 \mu \mathrm{M} \mathrm{NAA}+2.28$ $\mu \mathrm{M}$ BA $(5.5 \mathrm{mg}$ ) (Fig. 5d) accounted for the best results in terms of shoot dry mass. Root dry mass was significantly greater on MS enriched with $0.57 \mu \mathrm{M}$ NAA $(1.4 \mathrm{mg})$ when compared with the control $(0.5 \mathrm{mg})$. The lowest root dry mass production was verified in plants grown on MS supplemented with $2.28 \mu \mathrm{M}$ BA (Fig 5d).

In general, the concentration of photosynthetic pigments was not significantly affected by the hormonal ratios of benzyladenine and naphthaleneacetic acid assessed. Plants of the control treatment presented the highest chlorophyll $a$ level $\left(172 \mu \mathrm{g} \cdot \mathrm{g}^{-1}\right)$ whereas those cultured on MS supplemented with $2.28 \mu \mathrm{M}$ NAA $+0.57 \mu \mathrm{M}$ BA exhibited the greatest amounts of chlorophyll $b$ and carotenoids (87.6 $\mu \mathrm{g} \cdot \mathrm{g}^{-1}$; $66.1 \mu \mathrm{g} . \mathrm{g}^{-1}$, respectively). Plants grown on MS enriched with $2.28 \mu \mathrm{M}$ BA showed the lowest
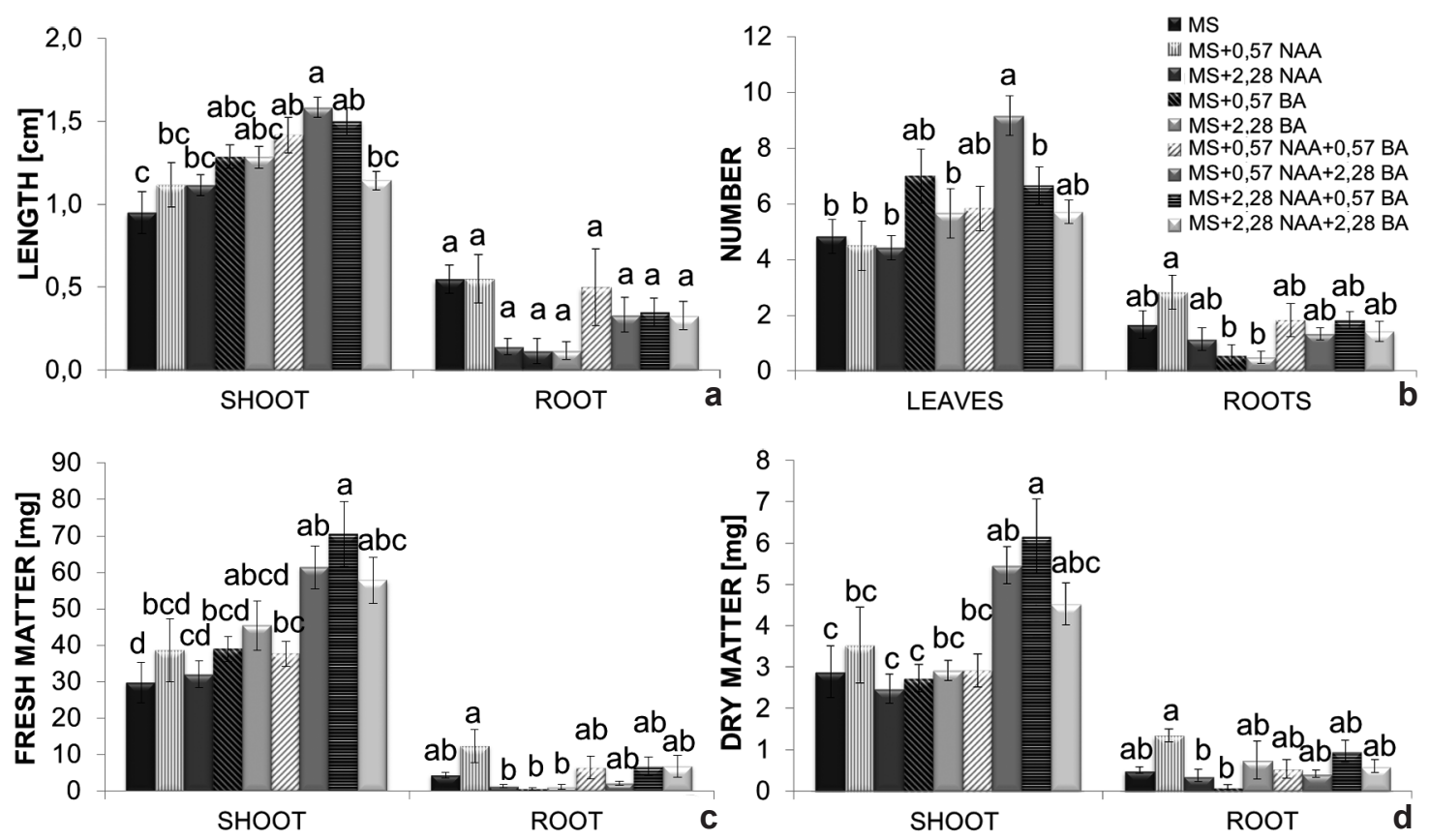

Figure 5 - a-d. Effects of benzyladenine (BA) and naphthaleneacetic acid (NAA); added to MS medium - a. on shoot and longest root length; b. number of leaves and roots; c. fresh mass; d. dry mass accumulation. Bars represent the standard error of the mean. Histobars with the same letters are not significantly different according to the Tukey's test at a $5 \%$ probability level $(n=8)$. 

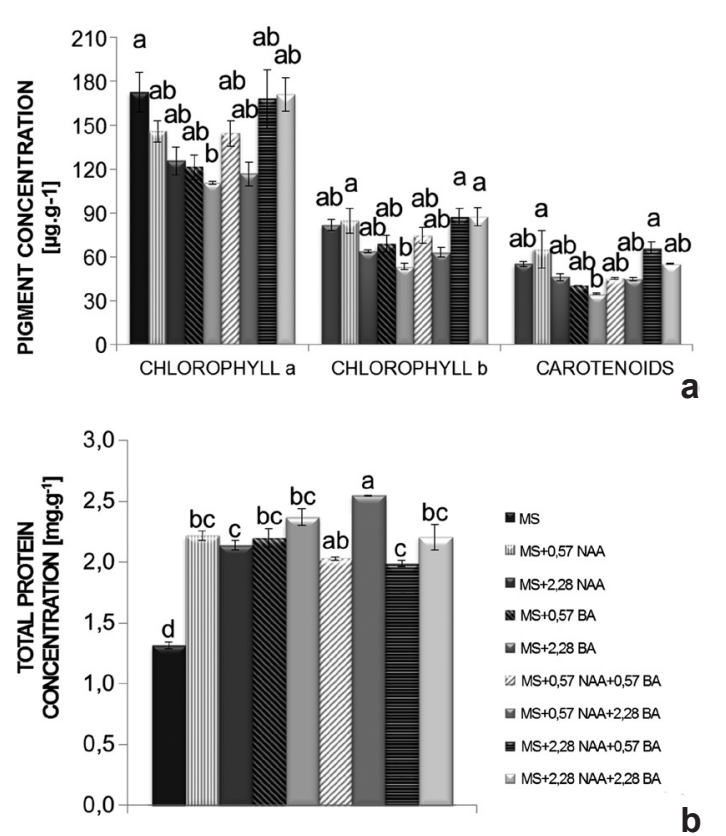

Figure 6 - a,b. Effects of benzyladenine (BA) and naphthaleneacetic acid (NAA) added to MS medium - a. on the amounts of photosynthetic pigments; $b$. on total protein. Bars represent the standard error of the mean. Histobars with the same letters are not significantly different according to the Tukey's test at a $5 \%$ probability level $(n=9)$.

concentrations of photosynthetic pigments: chlorophyll $a$, chlorophyll $b$ and carotenoids (110.4; 53.3 and $44.7 \mu \mathrm{g} . \mathrm{g}^{-1}$, respectively) (Fig. 6a).

Total protein concentration was stimulated by the presence of naphthaleneacetic acid and benzyladenine in the culture medium. Control plants had the lowest protein content $\left(1.3 \mathrm{mg} \cdot \mathrm{g}^{-1}\right)$. The plants produced more protein when grown on MS supplemented with $0.57 \mu \mathrm{M}$ NAA +2.28 $\mu \mathrm{M}$ BA and $2.28 \mu \mathrm{M}$ BA (2.5 and $2.4 \mathrm{mg} \cdot \mathrm{g}^{-1}$, respectively) (Fig. 6b).

\section{Acclimatization}

The two substrates tested did not significantly differ in terms of plant survival percentage (Sphagnum [64\%] and Sphagnum +Pinus bark [68\%]). The average shoot length of plants grown in Sphagnum + Pinus bark $(4.6 \mathrm{~cm})$ was higher than that of plants grown in Sphagnum alone $(3.4 \mathrm{~cm})$ (Fig. 7a). No significant difference was detected between the two substrates in terms of leaf number (Fig. 7b).

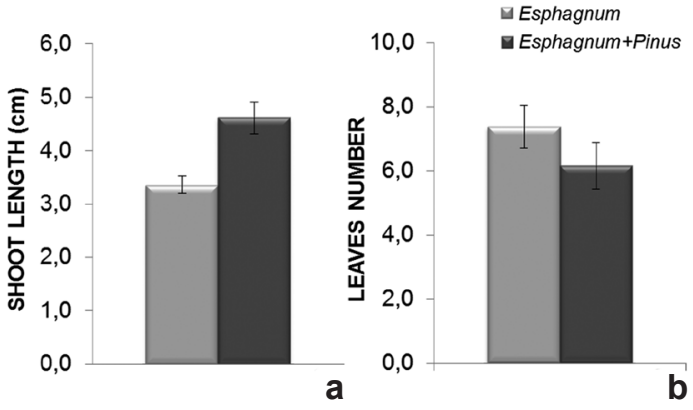

Figure 7 - a,b. Acclimatization of Cattleya xanthina - a. effects of two substrates on shoot length; b. leaf production. Bars represent the standard error of the mean and $*$ indicates a significant difference according to the Fisher's test at a $5 \%$ probability level $(n=9)$.

\section{Discussion}

KC medium slightly stimulated shoot growth in length as well as leaf formation in comparison with the other assessed media. Root development was enhanced on $\mathrm{KC}, \mathrm{VW}$ and MS/2 media, which have lower nutrient concentrations. MS medium inhibited root formation and growth in length, which could be related to its high nutrient concentration (Fig. 2a,b). Suzuki et al. (2009) also reported that MS inhibited root formation in Hadrolaelia tenebrosa (Rolfe) Chiron \& V.P. Castro. In contrast, Rego-Oliveira \& Faria (2005) verified that MS increased root length of Catasetum fimbriatum (C.Morren) Lindl. plants when compared to $\mathrm{KC}$ and $\mathrm{VW}$.

Well-developed roots are of utmost importance during acclimatization because they provide the seedlings the absorptive capacity to survive (Aoyama et al. 2012). For this reason, before carrying out acclimatization, the reduction of medium nutrient concentration is generally suggested (Preece \& Sutter 1991), as this enhances root formation and there is a greater chance of plant survival.

The greatest shoot fresh mass was obtained when plants were cultured on KC medium (Fig. $2 \mathrm{c}$ ), whereas root fresh mass was highest on VW. The interaction of calcium and ammonium in the VW medium actively promoted fresh mass accumulation in Dactylorhiza incarnata (Dijk \& Eck 1995), possibly due to the osmotic adjustment and water potential with lower calcium levels and higher amounts of ammonium (Shao et al. 2008). The same was observed for root fresh mass in C. xanthina (Fig. 2c). Shoot dry mass 
was significantly higher on KC medium (Fig. 2d), which has also been observed in Catasetum fimbriatum (Rego-Oliveira \& Faria 2005).

$\mathrm{MS} / 2$ provided the greatest root dry mass accumulation in C. xanthina whereas MS inhibited this parameter (Fig. 2d). Similar results were reported by Stancato et al. (2008) in Laelia longipes Rchb.f.. Studies with Hadrolaelia tenebrosa (Suzuki et al. 2009) also revealed that MS was extremely inhibitory to root fresh and dry mass. However, in Cattleya bicolor Lindl. Suzuki et al. (2010) verified that MS medium favored a greater root dry mass accumulation when compared to $\mathrm{KC}$ and VW. These results show again that the composition of the culture medium is extremely important for the development of orchids and that nutrient requirements vary among species. Therefore, it is of utmost importance to determine the most adequate nutritional demands for each species, especially for endangered ones.

The results obtained for the endogenous levels of $\mathrm{NO}_{3}{ }^{-}$and $\mathrm{NH}_{4}{ }^{+}$confirm the efficient uptake of nitrogen by $C$. xanthina on the culture media investigated. $\mathrm{KC}$ and $\mathrm{VW}$ media have a higher ammonium/nitrate ratio $(0.89,1.46$, respectively) whereas MS has the highest nitrate/ ammonium ratio (1.9) (Fig. 3a,b). In the present study, the high concentration of nitrate observed during seedling development may be due to the transient accumulation of this nutrient in the vacuoles (Rufty et al. 1986; Mantovani et al. 2005). Later, nitrate is converted into ammonium which is assimilated by the plant.

The synthesis of photosynthetic pigments was promoted in plants cultivated on $\mathrm{KC}$ medium (Fig. 3c), which has a balanced nitrate/ammonium ratio (1:1). The slight stimulation of shoot-related parameters on $\mathrm{KC}$ medium could be a result of the higher chlorophyll $a$ content in the tissues that possibly increased the photosynthetic rate. Chlorophyll plays the roles of absorbing light energy, activating the photosynthetic system and transforming it into chemical energy ( $\mathrm{Li}$ et al. 2013), which promotes vegetative growth. Increased synthesis of photosynthetic pigments and proteins (Fig. 3c,d) also benefits plant acclimatization, since natural habitats have reduced amounts of nutrients (Pospóšilová et al. 1999). The presence of ammonium ions stimulates faster amino acid and protein synthesis as well as cell division and expansion (Jiménez 2001; Gallardo et al. 2003); results confirmed by the present study.
The efficiency of shoot growth of C. xanthina on MS enriched with $0.57 \mu \mathrm{M}$ NAA $+2.28 \mu \mathrm{M}$ BA (Fig. 5a) confirms that a higher concentration of cytokinin promotes stem cell division and stimulates shoot development (Lexa 2003) as well as nutrient mobilization (Lo et al. 2004). Auxin/ cytokinin ratios favoring auxins tend to promote root development and those favoring cytokinins promote the development of shoots (Kefford \& Goldacre 1961; Su et al. 2011; Ori et al. 2014).

Root formation was inhibited by the addition of BA alone, and was slightly stimulated on MS enriched with $0.57 \mu \mathrm{M}$ NAA (Fig. 5b), which confirms the action of auxin on adventitious root formation by pericycle cells, responsible for initiating the processes of cell division and expansion (Casimiro et al. 2001). Similar results were observed in Cyrtopodium glutiniferum Raddi (Vogel \& Macedo 2010); in this study all auxin treatments resulted in the production of plants with larger roots when compared to treatments containing cytokinin only. The proposition of Krouk et al. (2011), that increased endogenous auxin levels promote root development thus enhancing absorption of nutrients, including nitrogen, which has a primary role in the composition of the chlorophyll molecule, was apparently not effective in C. xanthina plants.

The higher levels of total protein in $C$. xanthina when cultured on MS enriched with $0.57 \mu \mathrm{M}$ NAA $+2.28 \mu \mathrm{M}$ BA (Fig. 6b), can be correlated with high rates of mitotic divisions (Silveira et al. 2004), which could subsequently be responsible for the stimulation of shoot growth in length and leaf production (Fig. 5a,b). Also, the mobilization of cytokinins in shoots might be promoted when there is plenty of available nitrogen. Therefore, higher levels of cytokinin in the culture medium could have enhanced the use of nitrogen, promoting cell division and thus protein synthesis (Krouk et al. 2011).

Plant acclimatization was best when plants were grown in Sphagnum with the addition of Pinus bark. Cattleya xanthina is found in dense, ombrophilous forests (Dutra et al. 2015) at altitudes varying from 500 to 900 meters above sea level (BFG 2018). Humidity rates are decreased at high altitudes which also occur when plants are transferred to ex vitro conditions, especially when Pinus bark is used in the substrate mix as it retains little moisture.

Overall, $\mathrm{KC}$ was the most efficient medium for the growth of $C$. xanthina under in vitro 
conditions. It also stimulated the production of photosynthetic pigments and total protein. However, it caused high plant mortality when compared to MS. The addition of NAA and BA to MS medium was advantageous for $C$. xanthina plant development. Finally, the results showed that the concentration and form of nitrogen present in each culture medium are of utmost importance at every stage of plant development, providing active plant growth to ensure the urgent conservation of this orchid.

The present study establishes a propagation protocol for $C$. xanthina. The protocol followed with in vitro culture in $\mathrm{KC}$ culture medium for 180 days, transferred to MS medium with high level of auxin and low level of cytokinin, acclimatization in Sphagnum and Pinus bark with $80 \%$ shading, irrigation by nebulization and NPK fertilizer (20-20-20).

\section{Acknowledgements}

This work was supported by the Conselho Nacional de Desenvolvimento Científico e Tecnológico (CNPq), with a Master's Scholarship granted to the first author (Proc.132833/2013-1).

\section{References}

Aoyama EM, Versieux LM, Nievola CC \& MazzoniViveiros SC (2012) Avaliação da eficiência da propagação de Alcantarea imperialis (Bromeliaceae) cultivada in vitro e ex vitro. Rodriguésia 63: 321-331.

BFG - The Brazil Flora Group (2018) Brazilian Flora 2020: innovation and collaboration to meet Target 1 of the Global Strategy for Plant Conservation (GSPC). Rodriguésia 69: 1513-1527.

Bradford M (1976) A rapid and sensitive method for the quantitation of microgram quantities of protein using the principle of protein dye binding. Analytical Biochemistry 72: 248-254.

Casimiro I, Marchant A, Bhalerao RP, Beeckman T, Dhooge S, Swarup R, Graham N, Inzé D, Sandberg G, Casero PJ \& Bennett M (2001) Auxin transport promotes Arabidopsis lateral root initiation. The Plant cell 13: 843-52.

Cataldo DA, Haroon M, Schrader LE \& Youngs VL (1975) Rapid colorimetric determination of nitrate in plant tissue by nitration of salicylic acid. Communications in Soil Science and Plant Analysis 6: 71-80.

Cheng L (2003) Xanthophyll cycle pool size and composition in relation to the nitrogen content of apple leaves. Journal of Experimental Botany 54: 385-393.

Dijk E \& Eck N (1995) Ammonium toxicity and nitrate response of axenically grown Dactylorhiza incarnata seedlings. New Phytologist 131: 361-367.
Dutra D, Johnson TR, Kauth PJ, Stewart SL, Kane ME \& Richardson L (2008) Asymbiotic seed germination, in vitro seedling development, and greenhouse acclimatization of the threatened terrestrial orchid Bletia purpurea. Plant Cell, Tissue and Organ Culture 94: 11-21.

Dutra VF, Alves-Araújo A, Carrijo TT (2015) Angiosperm checklist of Espírito Santo: using electronic tools to improve the knowledge of an Atlantic Forest biodiversity hotspot. Rodriguésia 66: 1145-1152.

Ferreira WM \& Suzuki RM (2008) O cultivo in vitro de orquídeas como alternativa para a preservação de espécies nativas ameaçadas de extinção. In: Loiola MIB, Baseia IG \& Lichston JE (eds.) Atualidades, desafios e perspectiva da botânica no Brasil. Imagem Gráfica, Natal, 1: 67-68.

Gallardo K, Signor CL, Vandekerckhove J, Thompson RD \& Burstin J (2003) Proteomics of Medicago truncatula seed development establishes the time frame of diverse metabolic processes related to reserve accumulation. Plant Physiology 133: 664-682.

Hoehne FC (1953) Orchidaceas. In: Hoehne FC (ed.) Flora Brasilica. Secretaria da Agricultura, Industria e Comércio de São Paulo. São Paulo, 12: 1397.

Jiménez V (2001) Regulation of in vitro somatic embryogenesis with emphasis on to the role of endogenous hormones. Revista Brasileira de Fisiologia Vegetal 13: 196-223.

Kefford NP \& Goldacre PL (1961) The changing concept of Auxin. American Journal of Botany 48: 643-650.

Knudson L (1946) A new nutrient solution for germination of orchid seeds. American Orchid Society Bulletin 15: 214-217.

Krouk G, Ruffel S, Gutiérrez RA, Gojon A, Crawford NM, Coruzzi G \& Lacombe B (2011) A framework integrating plant growth with hormones and nutrients. Trends in Plant Science 16: 178-182.

Kuiper D, Schuit J \& Kuiper PJC (1988) Effects of internal and external cytokinin concentrations on root growth and shoot to root ratio of Plantago major ssp. Pleiosperma at different nutrient condition. Plant and Soil 111: 231-236.

Lexa M (2003) Dynamics of Endogenous Cytokinin Pools in Tobacco Seedlings: a Modelling Approach. Annals of Botany 91: 585-597.

Li D, Tian M, Cai J, Jiang D, Cao W \& Dai T (2013) Effects of low nitrogen supply on relationships between photosynthesis and nitrogen status at different leaf position in wheat seedlings. Plant Growth Regulation 70: 257-263.

Lichtenthaler HK (1987) Chlorophylls and Carotenoids: Pigments of Photosynthetic Biomembranes. Methods in Enzymology 148: 350-382.

Lo S-F, Nalawade SM, Kuo CL, Chen CL \& Tsay HS (2004) Asymbiotic germination of immature seeds, plantlet development and ex vitro establishment of plants of Dendrobium tosaense makino - A 
medicinally improrant orchid. In Vitro Cellular \& Developmental Biology - Plant 40: 528-535.

Magalhães JR, Huber DM \& Tsai CY (1992) Evidence of increased $15 \mathrm{~N}$-ammonium assimilation in tomato plants with exogenous $\alpha$-ketoglutarate. Plant Science 85: 135-141.

Malavolta E, Vitti GC \& Oliveira SA (1997) Avaliação do estado nutricional das plantas: princípios e aplicações. $2^{\text {nd }}$ ed. Associação Brasileira para Pesquisa da Potassa e do Fosfato, Piracicaba. 319p.

Mantovani JR, Ferreira ME \& Cruz MCP (2005) Produção de alface e acúmulo de nitrato em função da adubação nitrogenada. Horticultura brasileira 23: 758-762.

Mengel K \& Kirkby EA (1978) Principles of plant nutrition. International Potash Institute. WorblauBern, Switzerland. 593p.

MMA-Ministério do Meio Ambiente (2014) Lista Nacional Oficial de Espécies da Flora Ameaçadas de Extinção. Portaria MMA 443: 110-121.

Murashige T \& Skoog F (1962) A Revised Medium for Rapid Growth and Bio Assays with Tobacco Tissue Cultures. Physiologia Plantarum 15: 473-497.

Ori SS, Chu EP \& Tavares AR (2014) Effects of auxins on in vitro reserve compounds of Phalaenopsis amabilis (Orchidaceae). African Journal of Biotechnology 13: 1467-1475.

Pospóšilová J, Tichá I \& Kadleček P(1999)Acclimatization of micropropagated plants to ex vitro conditions. Biologia Plantarum 42: 481-497.

Preece JE \& Sutter EG (1991) Acclimatization of micropropagated plant to the greenhouse and field. In: Debergh PC \& Zimmerman RH (eds.) Micropropagation. Springer Netherlands, Netherlands 1: 71-93.

Rego-Oliveira L \& Faria R (2005) In vitro propagation of Brazilian orchids using traditional culture media and commercial fertilizers formulations. Acta Scientiarum-Agronomy 27: 1-4.
Rufty T, Thomas JF, Jill LR, Wilber HC \& Volk RJ (1986) Intercellular localization of nitrate reductase in roots. Plant physiology 82: 675-680.

Shao HB, Chu LY \& Shao MA (2008) Calcium as a versatile plant signal transducer under soil water stress. BioEssays 30: 634-41.

Silveira V, Floh E, Handro W \& Guerra M (2004) Effect of plant growth regulators on the cellular growth and levels of intracellular protein, starch and polyamines in embryogenic suspension cultures of Pinus taeda. Plant Cell, Tissue and Organ Culture 76: 53-60.

Stancato GC, Abreu MF \& Furlani ÂMC (2008) Crescimento de orquídeas epífitas in vitro: adição de polpa de frutos. Bragantia 67: 51-57.

Su YH, Liu YB \& Zhang XS (2011) Auxin-cytokinin interaction regulates meristem development. Molecular plant 4: 616-25.

Suzuki RM, Almeida V, Pescador R \& Ferreira WM (2010) Germinação e crescimento in vitro de Cattleya bicolor Lindley (Orchidaceae). Hoehnea 37: 731-742.

Suzuki RM, Moreira VC, Nakabashi M \& Ferreira WM (2009) Estudo da germinação e crescimento in vitro de Hadrolaelia tenebrosa (Rolfe) Chiron \& VP Castro (Orchidaceae), uma espécie da flora brasileira ameaçada de extinção. Hoehnea 36: 657-666.

Vacin EF \& Went FW (1949) Some pH Changes in Nutrient Solutions. Botanical Gazette 110: 605-613.

Vogel IN \& Macedo AF (2010) Influence of IAA, TDZ, and light quality on asymbiotic germination, protocorm formation, and plantlet development of Cyrtopodium glutiniferum Raddi., a medicinal orchid. Plant Cell, Tissue and Organ Culture 104: 147-155.

Weatherburn MW (1967) Phenol-hypochlorite reaction for determination of ammonia. Analytical Chemistry 39: 971-974. 